\title{
Comparison of three experimental designs employed in gentamicin microbiological assay through agar diffusion
}

\author{
Felipe Rebello Lourenço, Terezinha de Jesus Andreoli Pinto
}

Department of Pharmacy, CONFAR Laboratory, Faculty of Pharmaceutical Sciences, University of São Paulo

\begin{abstract}
Gentamicin is a broad-spectrum antibiotic complex produced by actinomycetes belonging to Micromonospora genus and classified among aminoglycoside antibiotics, used in the treatment of serious infections derived from Gram-negative microorganisms. Alterations of their antimicrobial activity not shown in chemical assays can be evaluated through microbiological assays. The aim of this work was to compare $5 \times 1,2 \times 2$ and $3 \times 1$ experimental designs, evaluating validation parameters of specificity, linearity, range, precision, and accuracy for each experimental design in different levels of concentration, presentation, and lots. It consisted of 81 assays (in 3 replicas) of gentamicin microbiological dosage. The concentrations of the solutions used were employed in a range from $1.0 \mu \mathrm{g} / \mathrm{mL}$ to $5.0 \mu \mathrm{g} / \mathrm{mL}$, diluted in phosphate buffer $0.1 \mathrm{M} \mathrm{pH}$ 8.0. Antibiotic medium number 11 was used, with Staphyloccocus epidermis (ATCC 12228). $21 \mathrm{ml}$ of medium were used as base layer and $4 \mathrm{ml}$ of medium inoculated at $1 \%$ were used as surface layer. The dishes were incubated for 18 hours at $37 \pm 1{ }^{\circ} \mathrm{C}$. The three designs employed showed adequate specificity for analysis of dermatological cream and injectable solution containing gentamicin sulphate. They also showed accuracy and linearity in the range evaluated, but not a significant difference concerning precision. The results were compared by means of the determination of the rates of measurement system capacity. The statistical analysis demonstrated that there is no significant difference among the results obtained through $5 \times 1,2 \times 2$, and $3 \times 1$, being these equivalent and interchangeable.
\end{abstract}

Uniterms: Gentamicin/sulphate. Antibiotics/experimental design. Gentamicin/microbiological dosage. Antibiotics/qualitative analysis. Aminoglycoside antibiotics/antimicrobial activity.

A gentamicina é um complexo antibiótico de largo espectro, produzido por actinomicetos do gênero Micromonospora e classificado entre os antibióticos aminoglicosídeos, utilizado no tratamento de infecções graves, devidas a microrganismos Gram-negativos. Alterações da sua atividade antimicrobiana, não demonstradas pelos ensaios químicos, podem ser avaliadas pelos ensaios microbiológicos. $\mathrm{O}$ objetivo deste trabalho foi comparar os delineamentos experimentais 5 x 1, 2 x 2 e 3 x 1, avaliando-se os parâmetros de validação de especificidade, linearidade, faixa ou intervalo, precisão e exatidão para cada delineamento experimental em diferentes níveis de concentração, apresentações e lotes. O plano de trabalho constituiu-se na realização de 81 ensaios (em 3 réplicas) de doseamento microbiológico de gentamicina. As concentrações das soluções empregadas foram preparadas numa faixa de $1,0 \mu \mathrm{g} / \mathrm{mL}$ a $5,0 \mu \mathrm{g} / \mathrm{mL}$, diluídos em tampão fosfato $0,1 \mathrm{M} \mathrm{pH} \mathrm{8,0.} \mathrm{O} \mathrm{meio} \mathrm{utilizado} \mathrm{foi} \mathrm{o} \mathrm{meio} \mathrm{antibiótico} \mathrm{no.} \mathrm{11,}$ com Staphyloccocus epidermidis (ATCC 12228). Empregou-se $21 \mathrm{~mL}$ de meio como camada base e 4 $\mathrm{mL}$ de meio inoculado à $1 \%$ como camada superfície. As placas foram incubadas por 18 horas à $37 \pm$ $1{ }^{\circ} \mathrm{C}$. Os três delineamentos empregados apresentaram especificidade adequada para análise de creme dermatológico e solução injetável contendo sulfato de gentamicina. Também apresentaram exatidão e linearidade no intervalo avaliado. Os delineamentos não apresentaram diferença significativa quanto a precisão. Os resultados foram comparados através da determinação de índices de capacidade do sistema de medição. A analise estatística demonstrou que não há diferença significativa entre os resultados obtidos pelos delineamentos 5 × 1, 2 × 2 e 3 × 1, sendo equivalentes e intercambiáveis.

Uniterms: Gentamicina/sulfat. Antibióticos/delineamento experimental. Gentamicina/doseamento microbiológico. Antibióticos/análite qualitativa. Antibióticos aminoglicosídeos/atividade antimicrobiana.

\footnotetext{
*Correspondência: F. R. Lourenço - Departamento de Farmácia - Faculdade de Ciências Farmacêuticas - Universidade de São Paulo - Av. Prof. Lineu Prestes, 580 - Bloco 13A - São Paulo - SP - Brasil - E-mail: feliperl@usp.br
} 


\section{INTRODUCTION}

The activity (potency) of antibiotics can be demonstrated under adequate conditions through their inhibitory effect over microbial growth. A reduction in the antimicrobial activity can reveal subtle alterations that are not demonstrable through chemical methods (United States Pharmacopeia, 2006). Besides this, biological assays do not require specialized equipment or high toxicity solvents (Pinto et al., 2003b). The agar diffusion and turbidimetric are the two biological methods more commonly employed for antibiotic dosage.

The turbidimetric method depends on the growth inhibition of a microbial culture in an antibiotic uniform solution in fluid medium, which must be favorable to a quick microbial growth in the absence of antibiotic. This method takes into account the relation between the proportion of growth of a microbial population in the liquid medium and the concentration of the assayed substance, being mostly used for vitamin and aminoacid dosage.

The agar diffusion method depends on the antibiotic diffusion through a layer of solidified agar, in an extension that totally inhibits the growth of the microorganism in an area or zone around the reservoir containing antibiotic solution. In this assay the size of the inhibition zone and the dose of the substance assayed are correlated. This is the most widely employed method to determine the potency of antibiotics. The diffusion method employs inoculated solid culture medium, distributed in dishes, in a system of mono or double layers, through which the test-substance spreads. The test-solution is applied on the surface of this medium in a restricted area, being the dishes then incubated: the microorganism growth occurs, respecting however the areas in which the antibiotic diffusion has occurred, generating contrast and resulting in the so-called growth inhibition zone. Such phenomenon originates all the theory that is the fundament of the diffusion method.

The official compendia and pharmacopoeias include antibiotic microbiological dosage assays. However, there is no consensus regarding the experimental designs. The balanced designs $3 \times 3$ and $2 \times 2$ are adopted by the Brazilian (Farmacopéia Brasileira, 1988) and British (British Pharmacopoeia, 2004) pharmacopoeias, whereas the American (United States Pharmacopeia, 2006) pharmacopoeia presents $5 \times 1$ design for antibiotic dosage. The use of an adequate experimental design in relation to the criteria of linearity, precision, and accuracy of the analytical results is fundamental. It is highly advisable to adopt an experimental planning which, without further effort, supplies better results and enables an indication respecting the assay validity. The number and nature of the samples, as well as the results reliability level, are among the most important factors to be taken into account, in the selection of a design.

The $2 \times 2$ assay, known as symmetrical or balanced, is a simple and efficient design which employs two doses of the standard and two other of the sample, with identical ratio between the doses in both preparations. Each dish includes all the four doses, in such a way that the number of replicas equals that of dishes (Knudsen, 1945a; Knudsen 1945b; Knudsen, Randall, 1945). The 5 x 1 assay, known as interpolation in standard curve assay, is a design with a standard curve of five concentrations. Each dish includes two doses, in alternate positions, being one of the concentrations in all the dishes a reference (central concentration of standard curve) and the other, one of the four standard concentrations, or the one corresponding to the sample dose with unknown potency (nominal dose equivalent to the standard reference) (Dart, 1966 United States Pharmacopeia, 2006). Both designs present advantages and disadvantages. The validation of the analytical method is always fundamental to guarantee the quality of results. Linearity, accuracy and precision are some of the most important parameters for analytical method validation.

We can, therefore, observe that the determination of antimicrobial potency is extremely important for the control and quality assurance concerning pharmaceutical preparations, being thus necessary to develop practical and economical procedures which can be applied in the validation and dosage of drugs (Marques, 1988; Yamamoto, 1994; 1996).

The association of the positive characteristics of $2 \mathrm{x}$ 2 and $5 \times 1$ designs would probably be of considerable interest, as it could improve validation parameters, generating safer and more reliable results. This fact not only makes the comparison between different types of designs justifiable, as proposed by this project, but also the development of an alternative design which gathers all the necessary characteristics for safe and reliable analytical results.

The need for confirmation in terms of medicaments therapeutic efficacy is a concerning issue. There are situations in which the margin between the inefficient dose, under the therapeutic point of view, and a toxic dose is relatively small. Furthermore, even if the starting-point of the toxic dose is not reached, there is the economical aspect to be considered, as well as falsification with structurally similar molecules (Cooper, 1963; Pinto et al., 2003b).

Gentamicin, the first isolated antibiotic from the Micromonospora genera with therapeutic importance, has its potency microbiologically determined through the agar diffusion method (Oden, 1972; Campos, 1982), employing $2 \times 2$ or $5 \times 1$ designs, according to Brazilian (Farmacopéia Brasileira, 1988) and American pharmacopoeias (United 
States Pharmacopeia, 2006), respectively.

The association of $2 \times 2$ and $5 \times 1$ positive design characteristics would be considerably interesting, once it could improve the validation parameters, generating safer and more reliable results. The $3 \times 1$ design, proposed in this work, is an interpolation in the standard curve assay, which employs three doses of standard and one of sample, with nominal concentration equivalent to the standard median dose, including each dish all the preparations.

The aim of this work was to propose the use of 3 $\mathrm{x} 1$ experimental design for gentamicin microbiological dosage and to compare specificity, linearity, range, accuracy, and precision characteristics to those of $2 \times 2$ and 5 $\mathrm{x} 1$ experimental designs, commonly employed in gentamicin microbiological dosage in different pharmaceutical preparations.

\section{MATERIALS AND METHODS}

\section{Assay Method}

Twenty seven samples of raw material were evaluated, as well as injectable solution and dermatological cream containing gentamicin sulphate. Each sample was assayed in 3 replicas using $2 \times 2,5 \times 1$, and $3 \times 1$ designs, in a total of 243 assays.

The standard solutions and samples were prepared using $0.1 \mathrm{M} \mathrm{pH} 8.0$ phosphate buffer as diluent. The concentrations used for $2 \times 2$ design were $2.0 \mu \mathrm{g} / \mathrm{mL}$ (P1 and $\mathrm{A} 1$ ) and $4.0 \mu \mathrm{g} / \mathrm{mL}$ (P2 and A2). For $5 \times 1$ design the concentrations were $1.3 \mu \mathrm{g} / \mathrm{mL}(\mathrm{P} 1), 1.6 \mu \mathrm{g} / \mathrm{mL}$ (P2), $2.0 \mu \mathrm{g} \mathrm{mL}$ (P3), $2.5 \mu \mathrm{g} / \mathrm{mL}$ (P4), and $3.1 \mu \mathrm{g} / \mathrm{mL}$ (P5) for standard, and $2.0 \mu \mathrm{g} / \mathrm{mL}$ (A) for the sample. As for $3 \mathrm{x}$ 1 design the following concentrations were employed: $1.0 \mu \mathrm{g} / \mathrm{mL}$ (P1), $2.0 \mu \mathrm{g} / \mathrm{mL}$ (P2), and $4.0 \mu \mathrm{g} / \mathrm{mL}$ (P3) for standard, and $2.0 \mu \mathrm{g} / \mathrm{mL}$ (A) for the sample. The dishes were prepared with $21 \mathrm{~mL}$ of antibiotic medium $\mathrm{n}^{\circ} 11$. After the base layer solidification $4 \mathrm{ml}$ of $\mathrm{n}^{\circ} 11$ antibiotic medium inoculated with Staphylococcus epidermidis (ATCC 12228) were added in a $1 \%$ proportion. Paper discs (Schleicher and Schuell ${ }^{\circledR}$ ), with a diameter of 12.7 $\mathrm{mm}$, previously immersed in standard or sample solutions and having had the volume excess removed according to standards, were distributed in accordance with the experimental design employed.

The dishes were incubated in a Nova Ética (Mod. $411 \mathrm{D}$ ) incubator for 18 hours at $37 \pm 1{ }^{\circ} \mathrm{C}$. After incubation the diameters of the inhibition halos were measured in millimeters with the help of an Eli Lilly Antibiotic Zone Re$a_{d e r}{ }^{\circledR}$. The results were then recorded and the calculations made according to the experimental design employed.

\section{$2 \times 2$ Design}

In this assay, each dish includes all the doses, being the unknown low and high standard and sample potencies distributed in opposed positions. Figure 1 indicates the disposition of paper discs (Schleicher and Schuell ${ }^{\circledR}$ ) in each Petri dish. For each sample assayed by means of $2 \times 2$ experimental design, 6 dishes were employed.

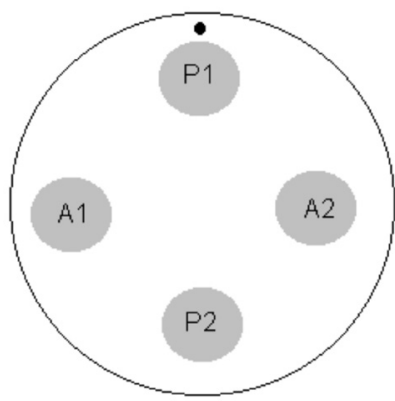

FIGURE 1- Disposition of paper discs in each Petri plate for $2 \times 2$ design.

The results obtained in this assay were calculated according to Hewitt (1977), as shown in the equations below. Each assay was evaluated through variance analysis (ANOVA) as to regression and parallelism, to guarantee the validity of the test.

Where: A1, A2, P1 and P2 are the means of diameters of the inhibition halos for low-dose sample solution, high-dose sample solution, low-dose standard solution and high-dose standard solution, respectively; $\mathrm{M}$ is the potency estimation and 2 is the dose ratio.

\section{$5 \times 1$ Design}

In this assay, each dish contains two doses in alternate position, being one of the concentrations in all the dishes a reference (central concentration of the standard curve), while the other, one of the standard four concentrations or the dose of the unknown potency sample (nominal dose equivalent to standard reference). Figure 2 indicates the disposition of the paper discs (Schleicher and $S c h u e l l^{\circledR}$ ) on each Petri dish. Sixteen dishes were employed in the standard curve and four in each sample assayed by means of experimental design $5 \times 1$.

After the correction of the curve points, the results of the $5 \times 1$ assays were calculated according to Hewitt (1977), as shown in the equations below. For 


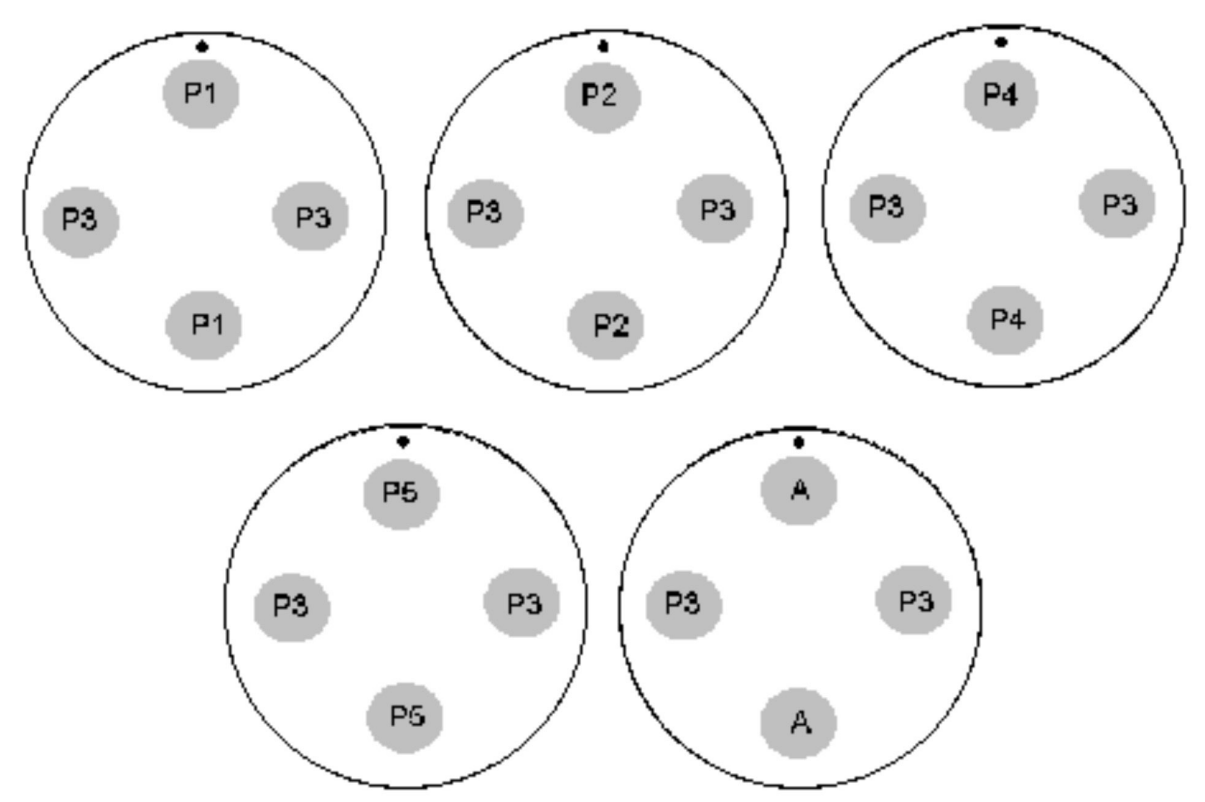

FIGURE 2 - Disposition of paper discs in each Petri plate for 5x1 design.

the purpose of assay validation, each standard curve was evaluated, through variance analysis, as to linearity and regression.

Where: P1, P2, P3, P4 and P5 are the means of diameters of the inhibition halos for standards solutions; $\mathrm{A}$ is the mean of diameters of inhibition halos for sample solution; $\mathrm{M}$ is the potency estimation and 1.25 is the dose ratio.

\section{$3 \times 1$ Design}

In this assay, each dish includes all the doses, having the median standard dose and the dose of the unknown potency sample been distributed in opposed positions. Figure 3 indicates the disposition of the paper discs (Schleicher and Schuell ${ }^{\circledR}$ ) on each Petri dish. Six dishes were employed for each sample assayed through $3 \times 1$ experimental design (Lourenço, Pinto, 2007a; Lourenço, Pinto, 2007b; Pinto et al., 2007).

The results of these assays were calculated as shown in the equations above. Each assay was evaluated, through variance analysis, as to linearity and regression in order to guarantee the test validity.

Where: A, P1, P2 and P3 are the means of diameters of the inhibition halos for sample solution, lowdose standard solution, median-dose standard solution and high-dose standard solution, respectively; $\mathrm{M}$ is the potency estimation and 2 is the dose ratio.

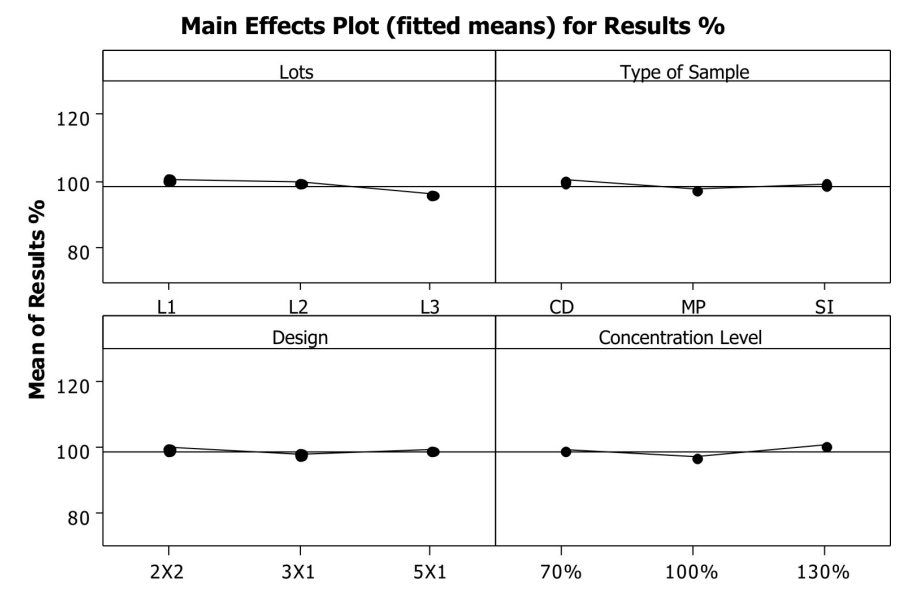

FIGURE 3 - Disposition of paper discs in each Petri plate for $3 \times 1$ design.

\section{Method Validation}

The experimental designs employed in gentamicin microbiological dosage were evaluated as to specificity, accuracy, precision, linearity, and range (ICH, 1996; Brasil, 2002; Inmetro, 2003; Pinto el al., 2003a).

Specificity was evaluated by means of the comparison of the diameters of the haloes obtained from gentamicin solution and gentamicin solution with the excipients of the dosage form evaluated. The haloes diameters were compared as to dispersion, using F-Snedecor test, and position, using t-Student test (Inmetro, 2003; Beiguelman, 2002; Calleguri-Jacques, 2003). 
Accuracy was evaluated in relation to fixed tendency and relative tendency and was determined through linear regression analysis, by plotting theoretical concentrations versus experimentally determined concentrations. The straight line equation, concerning the accuracy of each experimental design, was estimated through 81 experimental determinations in three levels of concentration $(70 \%, 100 \%$, and $130 \%$ of the reference dose) in raw material, injectable solution and dermatological cream. It has been concluded that the methods are accurate, that is, they do not present fixed or relative tendency when the reliability intervals for linear and angular coefficients include, respectively, values 0 and 1 (Caulcutt, Boddy, 1982; Beiguelman, 2002; Calleguri-Jacques, 2003).

Precision was evaluated through the standard deviation determined from 81 experimental determinations in three concentration levels $(70 \%, 100 \%$, and $130 \%$ of the reference dose) in raw material, injectable solution, and dermatological cream. The designs were compared as to precision through Bartlett and Levene tests. It was also evaluated if precision is associated with concentration through linear regression analysis, by plotting relative standard deviation versus concentration. This resulted in the verification that precision is not associated to concentration when the angular coefficient reliability interval includes value 0 (Caulcutt, Boddy, 1982; Beiguelman, 2002; Calleguri-Jacques, 2003).

Linearity was evaluated through linear regression analysis by correlation coefficient and the regression significance. It was verified that the methods present linearity when the correlation coefficient ( $\mathrm{r}$ ) is bigger or equal to 0.90 and the regression significance is inferior to 0.01 (Caulcutt, Boddy, 1982; Beiguelman, 2002; CalleguriJacques, 2003).

RE 899 resolution (Brasil, 2002), states that the recommended range for methodology of analytical quantitative determination in raw materials or dosage forms varies from $80 \%$ to $120 \%$ of the theoretical concentration. However, the specification for gentamicin, in the form of dermatological cream, described in USP 29 (United States Pharmacopeia, 2006), varies from $90 \%$ to $130 \%$ of the theoretical concentration. Thus the evaluation of the range was performed from $70 \%$ to $130 \%$ of the theoretical concentration. The interval was established by the confirmation that the method shows adequate accuracy, precision, and linearity.

\section{Comparison of different designs}

The comparisons of the designs were performed by determining the measurement system capacity rates (Mon- tgomery, 2004). The latter were estimated by the ratio between the amplitude of the results under a determined condition and the linear range of the method employed ( $70 \%$ to $130 \%$ of the theoretical concentration). The rates evaluate the influence of the difference of the design in relation to the method application (Montgomery, 2004).

There is no significant influence of the type of design employed for values inferior to $10 \%$, being the methods interchangeable. For values between $10 \%$ and $30 \%$ there is small influence, but still acceptable. When the values exceeded $30 \%$ the influence of the type of design employed was considered great, thus being impossible to ensure the methods interchange (Montgomery, 2004).

\section{RESULTS AND DISCUSSION}

The results of gentamicin microbiological dosage of raw material, injectable solutions and dermatological creams through $2 \times 2,5 \times 1$, and $3 \times 1$ designs are in Table I.

The assays of $2 \times 2$ design were considered valid as to the regression significance $(\mathrm{p}<0.01)$ and parallelism $(\mathrm{p}>0.05) .5 \times 1$ design curves were considered valid as to linearity $(r>0.90)$ and regression significance $(\mathrm{p}<0.01)$. The results obtained through $3 \times 1$ design were considered valid as to linearity $(r>0.90)$ and regression significance $(\mathrm{p}<0.01)$.

In what concerns validation, $2 \times 2,5 \times 1$, and $3 \times$ 1 experimental designs presented specificity, accuracy, precision, linearity, and range adequate to the application of the methods.

The methods showed adequate specificity relatively to the injectable solution and the dermatological cream containing gentamicin sulphate.

Snedecor $F$ tests demonstrated that there was no significant effect of the matrix as to the precision of the responses obtained. Student $t$ tests demonstrated the absence of the matrix effect relatively to the injectable solution and the dermatological cream containing gentamicin sulphate. It has been thus guaranteed that the response obtained (inhibition halos diameter) is associated to the amount of gentamicin in the formulation.

The methods were considered accurate when the reliability intervals of linear and angular coefficients include, respectively, values 1 and 0 . None of the three designs showed fixed or absolute tendency and relative tendency, not being necessary to employ any kind of correction or adjustment of the results obtained.

The methods precision was quantified by the estimation of the standard deviation of each design evaluated. The estimation of the standard deviation was determined by the square root of the variance analysis residual error for each 
TABLE I - Results of 27 samples evaluated through 2 × 2, 5 x 1, and 3 x 1 designs

\begin{tabular}{|c|c|c|c|c|c|c|c|c|c|}
\hline \multirow{3}{*}{ Level } & \multicolumn{9}{|c|}{$2 \times 2$ Design } \\
\hline & \multicolumn{3}{|c|}{ Raw Material } & \multicolumn{3}{|c|}{ Injectable solution } & \multicolumn{3}{|c|}{ Dermatological cream } \\
\hline & Lot A & Lot B & Lot C & Lot A & Lot B & Lot C & Lot A & Lot B & Lot $\mathrm{C}$ \\
\hline & 67,7 & 62,6 & 70,0 & 64,2 & 64,5 & 64,9 & 70,5 & 80,5 & 69,5 \\
\hline \multirow[t]{3}{*}{$70 \%$} & 74,3 & 68,4 & 62,9 & 63,3 & 76,6 & 63,4 & 84,8 & 78,5 & 73,9 \\
\hline & 73,4 & 68,2 & 68,2 & 62,7 & 71,3 & 69,6 & 78,3 & 74,1 & 69,6 \\
\hline & 98,4 & 101,1 & 90,9 & 100,1 & 94,7 & 95,9 & 97,7 & 100,9 & 88,3 \\
\hline \multirow[t]{3}{*}{$100 \%$} & 100,7 & 92,7 & 94,0 & 99,7 & 98,7 & 93,7 & 105,2 & 104,7 & 94,5 \\
\hline & 97,9 & 98,9 & 91,5 & 101,0 & 92,5 & 96,5 & 100,8 & 93,2 & 99,5 \\
\hline & 136,9 & 123,6 & 121,3 & 129,3 & 125,1 & 128,2 & 143,9 & 137,3 & 125,4 \\
\hline \multirow[t]{3}{*}{$130 \%$} & 129,0 & 132,0 & 133,0 & 122,3 & 129,0 & 128,2 & 162,0 & 135,1 & 122,4 \\
\hline & 134,3 & 123,2 & 131,3 & 138,6 & 139,3 & 129,4 & 130,3 & 128,0 & 128,8 \\
\hline & & & & \multicolumn{3}{|c|}{$5 \times 1$ Design } & & & \\
\hline \multirow[t]{3}{*}{ Level } & \multicolumn{3}{|c|}{ Raw Material } & \multicolumn{3}{|c|}{ Injectable solution } & \multicolumn{3}{|c|}{ Dermatological cream } \\
\hline & Lot A & Lot B & Lot C & Lot A & Lot B & Lot C & Lot A & Lot B & Lot $\mathrm{C}$ \\
\hline & 75,8 & 69,9 & 64,0 & 86,3 & 70,4 & 70,1 & 75,8 & 76,7 & 65,8 \\
\hline \multirow[t]{3}{*}{$70 \%$} & 72,6 & 66,9 & 67,8 & 69,3 & 72,5 & 68,5 & 72,6 & 74,5 & 62,7 \\
\hline & 72,3 & 66,6 & 62,1 & 64,3 & 72,5 & 65,7 & 72,3 & 74,1 & 70,4 \\
\hline & 96,8 & 96,9 & 89,9 & 108,4 & 103,8 & 94,0 & 96,8 & 101,6 & 93,2 \\
\hline \multirow[t]{3}{*}{$100 \%$} & 96,2 & 94,1 & 97,2 & 96,1 & 102,9 & 99,2 & 96,2 & 98,4 & 83,2 \\
\hline & 96,2 & 100,9 & 89,9 & 97,5 & 102,5 & 100,3 & 96,2 & 100,9 & 95,4 \\
\hline & 134,9 & 136,9 & 130,4 & 135,4 & 148,6 & 132,5 & 134,9 & 138,7 & 126,5 \\
\hline \multirow[t]{3}{*}{$130 \%$} & 120,5 & 133,2 & 129,0 & 125,2 & 121,5 & 137,6 & 120,5 & 133,4 & 109,2 \\
\hline & 133,6 & 132,7 & 132,0 & 124,6 & 127,4 & 123,6 & 133,6 & 142,9 & 117,9 \\
\hline & \multirow{2}{*}{\multicolumn{3}{|c|}{ Raw Material }} & \multicolumn{3}{|c|}{$3 \times 1$ Design } & & & \\
\hline \multirow[t]{3}{*}{ Level } & & & & \multicolumn{3}{|c|}{ Injectable solution } & \multicolumn{3}{|c|}{ Dermatological cream } \\
\hline & Lot A & Lot B & Lot C & Lot A & Lot B & Lot C & Lot A & Lot B & Lot $\mathrm{C}$ \\
\hline & 64,1 & 58,8 & 66,0 & 78,3 & 75,0 & 68,6 & 79,6 & 71,6 & 56,9 \\
\hline \multirow[t]{3}{*}{$70 \%$} & 68,1 & 69,2 & 69,3 & 62,2 & 64,6 & 68,9 & 66,8 & 60,3 & 70,9 \\
\hline & 64,0 & 72,9 & 71,3 & 65,7 & 63,7 & 71,2 & 75,1 & 62,9 & 61,7 \\
\hline & 89,7 & 87,8 & 95,7 & 106,5 & 103,4 & 101,3 & 94,7 & 99,1 & 81,1 \\
\hline \multirow[t]{3}{*}{$100 \%$} & 102,2 & 101,9 & 99,6 & 102,7 & 96,7 & 97,1 & 99,2 & 95,4 & 92,5 \\
\hline & 99,5 & 88,0 & 93,6 & 100,5 & 97,2 & 107,5 & 92,8 & 102,3 & 100,2 \\
\hline & 128,3 & 113,1 & 127,8 & 120,8 & 129,6 & 138,1 & 144,8 & 124,5 & 123,5 \\
\hline \multirow[t]{2}{*}{$130 \%$} & 143,2 & 125,8 & 127,5 & 143,8 & 125,0 & 132,6 & 141,7 & 134,2 & 119,3 \\
\hline & 115,5 & 142,9 & 132,6 & 123,6 & 125,1 & 132,6 & 126,3 & 139,9 & 127,1 \\
\hline
\end{tabular}

Results expressed in \%.

design. Bartlett and Levene tests indicated that there is no significant difference of precision in the designs evaluated. It has also been verified that precision is not associated to concentration when the angular coefficient reliability interval includes valueThe results demonstrated that there is linear association between the inhibition halos diameter and the logarithm of concentration, having in all the assays been obtained correlation coefficient above 0.90 and significant regression $(\mathrm{p}<0.01)$. The study showed adequate linearity, accuracy and precision in the range of $1.0 \mu \mathrm{g} / \mathrm{mL}$ to $4.0 \mu \mathrm{g} / \mathrm{mL}$.

Table II shows the measurement system capacity rates. It has been concluded that there is no significant 
influence of the evaluated factor for values under $10 \%$. When the latter range between $10 \%$ and $30 \%$ there is little influence, yet still acceptable. When values exceeded $30 \%$ the influence verified was great. The results demonstrated that the evaluated factors do not present significant influence on the methods application range (70\% to $130 \%$ of the theoretical concentration). This implies that the differences found among the results obtained in different concentrations (designs, types of samples, concentration levels, and preparation lots) were not significant when compared to the methods application range.

TABLE II - Capacity rates of the effects of different lots, types of samples, designs, and concentration levels.

\begin{tabular}{lc}
\hline Type of Effect & Capacity rate (\%) \\
\hline Lot & $7,6^{*}$ \\
Type of sample & $4,6^{*}$ \\
Design & $3,8^{*}$ \\
Concentration level & $7,9^{*}$ \\
\hline
\end{tabular}

* There is no significant influence.

The effect graphs (Figure 4) indicate the differences among the varied conditions evaluated relatively to the methods application range.

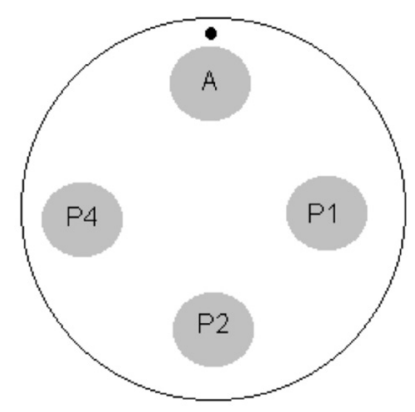

FIGURE 4 - Graphs of effects of different lots, types of samples, designs and concentration levels.

All the designs of the microbiological method presented adequate specificity in the analysis of injectable solution and dermatological cream containing gentamicin sulphate. The statistical tests demonstrated absence of matrix effect. $3 \times 1$ design showed adequate accuracy, not revealing fixed and relative tendencies in the evaluation of gentamicin sulphate raw material, injectable solution, and dermatological cream containing gentamicin, what was also verified in $2 \times 2$ and $5 \times 1$ designs. There is therefore no need to correct the results obtained by the methods studied. $3 \times 1$ design showed adequate precision in the evaluation of gentamicin sulphate raw material, injectable solution, and dermatological cream containing gentamicin, not presenting significant difference relatively to $2 \times 2$ and $5 \times 1$ designs. The values of relative standard deviation for $2 \times 2,5 \times 1$, and $3 \times 1$ designs were, respectively, $6.8 \%$, $7.1 \%$, and $6.4 \%$. The statistical evaluation showed that there is no association between the method precision and the concentration of gentamicin in the samples evaluated, what proves the homoscedasticity of the method, which presented significant regression and satisfactory linearity in the studied range of $1.0 \mu \mathrm{g} / \mathrm{ml}$ to $4.0 \mu \mathrm{g} / \mathrm{ml}$. The method application range was $70 \%$ to $130 \%$ of the theoretical concentration.

The designs studied were equivalent in the evaluation of gentamicin sulphate raw material, injectable solution, and dermatological cream containing gentamicin. The differences found among the results obtained in different conditions (designs, types of samples, concentration levels, and preparation lots) were insignificant when compared to the method application range.

The $2 \times 2$ assay is recommendable for research and development, as it supplies information about the regression significance and parallelism between the standard curve and the sample, what permits the evaluation of the test validity. The $5 \times 1$ assay proved to be appropriate for routine analysis in quality control laboratories, as it makes the simultaneous evaluation of a high number of samples possible. However, the necessity of correction makes calculations complicated and more susceptible to mistakes. The $3 \times 1$ showed adequacy for routine analysis in quality control laboratories, as it simplifies the test execution and the potency calculation, besides offering advantages in terms of low cost and the material involved.

The proposed design can be applied to other antibiotics dosage. It is only necessary to evaluate the regression significance and the linearity of the curve employed.

\section{REFERENCES}

BEIGUELMAN, B. Curso prático de bioestatística. 5.ed. Ribeirão Preto: FUNPEC, 2002. p.1-35, 117-263.

BRASIL, Resolução RE no. 899 de 29 de maio de 2003. Diário Oficial da União, Brasília, 02 de junho de 2003. Determina a publicação do "Guia para validação de métodos analíticos e bioanalíticos"; fica revogada a Resolução RE no 475, de 19 de março de 2002. Available at: <http://e-legis.anvisa.gov.br/ leisref/public/showAct.php?id=15132\&word=Valida \%c3\%a $7 \%$ c3\%a3o $>$. Accessed on: $7^{\text {th }}$ oct. 2004. 
BRITISH pharmacopoeia. London: Her Majesty's Stationery Office, 2004. v.4, Appendix XIV A.A279-A285.

CALLEGARI-JACQUES, S.M. Bioestatística: princípios e aplicações. Porto Alegre: Artmed, 2003. p. 19-105, 153-164.

CAMPOS, L.M.M.; SCHAPOVAL, E.E.S. Controle de qualidade de produtos farmacêuticos contendo gentamicina. An. Farm. Quím. S. Paulo, v.22, n.1-2, p.27-33, 1982.

CAULCUTT, R., BODDY, R. Statistics for analytical chemists. London: Chapman \& Hall, 1983. 253 p.

COOPER, K.E. The theory of antibiotics inhibition zones. In: KAVANAGH, F., (Ed.). Analytical microbiology. New York: Academic Press, 1963. v.1, p.1-83.

DART, R.K. Microbiology for the analytical chemist. Cambrigde: The Royal Society of Chemistry, 1966. p.133-149.

FARMACOPÉIA BRASILEIRA. 4.ed. São Paulo: Atheneu, 1988. pt.1, p.V.5.2.17-V.5.2.17-15.

HEWITT, W. Microbiologycal assay. Orlando: Academic Press, 1977. p.17-68,136-150, 214-242.

INMETRO. Instituto Nacional de Metrologia, Normalização e Qualidade Industrial - DOQ-CGCRE-008 Revisão 01 Março/2003 - Orientações sobre validação de métodos de ensaios químicos. Rio de Janeiro, 2003. 35 p.

KNUDSEN, L.F. Penicillin assay. Science, v.101, n.2611, p.46-48, 1945.

KNUDSEN, L.F. The use of statistics in biological experimentation and assay.J.Assoc. Off. Agric. Chem., v.28, n.4, p.806-813, 1945.

KNUDSEN, L.F., RANDALL, W.A. Penicillin assay and its control chart analysis. J. Bacteriol., v.50, n.2, p.187-200, 1945.

LOURENÇO, F. R.; PINTO, T. J. A. Doseamento microbiológico de gentamicina - Um novo delineamento experimental. Rev. Bio Farma-Rev. Téc. Cient. Farm. Bioquím. Anál. Clín. Toxicol., v.2, n.4, p.305-310, 2007.

LOURENÇO, F. R.; PINTO, T. J. A. Comparison of three experimental designs employed in gentamicin microbiological assay through agar diffusion. In: WORLD CONGRESS OF PHARMACY AND PHARMACEUTICAL SCIENCES 2007 - CONGRESS OF FIP, 67., 2007. Abstracts. Beijing, 2007. v.1. p.171-171.
MARQUES, M.R.C., HACKMANN, E.R.M., SAITO, T. Doseamento microbiológico de neomicina: influência do volume de meio de cultura. Rev. Farm. Bioquím. Univ. S. Paulo, v.24, n.1, p.12-18, 1988.

MONTGOMERY, D.C. Análise da capacidade de processos e sistemas de medida. In: MONTGOMERY, D.C., (Ed.). Introdução ao controle estatístico da qualidade. Rio de Janeiro: LTC, 2004. p. 220-252.

ODEN, E.M.; WAGMAN, G.H.; WEINSTEIN, M.J. Gentamycin. In: KAVANAGH, F., ed. Analytical Microbiology. New York: Academic Press, 1972. v. 2, p. 271-284.

PINTO, T.J.A., FERRARINI, M., GATTI, R.M. Proposta de roteiro prático para a validação de métodos analíticos. Farm. \& Quím., v.36, n.1, p.26-36, 2003

PINTO, T.J.A., KANEKO, T.M., OHARA, M.T. Controle biológico de qualidade de produtos farmacêuticos, correlatos e cosméticos. 2.ed. São Paulo: Atheneu, 2003. p.7-56, 261-287.

PINTO, T. J. A.; LOURENÇO, F. R.; KANEKO, T. M. Microbiological assay of gentamycin employing an alternative experimental design. In: AOAC ANNUAL MEETING \& EXPOSITION, 121., 2007. Anais. Anahein-Califórnia, 2007. v. 1.p. 157-157.

PROCEEDINGS OF THE INTERNATIONAL CONFERENCE ON HARMONISATION (ICH). Commission of the European Communities. Validation analytical procedures. [s.l.], [s.n.], 1996. $17 \mathrm{p}$.

UNITED STATES PHARMACOPEIA. 29.ed. Rockville: The United States Pharmacopeia Convention, 2006. p. 2513-2520.

YAMAMOTO, C.H. Dosagem microbiológica de neomicina por difusão em Agar. Redução do tempo de análise pela aplicação do cloreto de trifeniltetrazolio. São Paulo, 1994, 169p. [Dissertação de mestrado. Faculdade de Ciências Farmacêuticas. Universidade de São Paulo].

YAMAMOTO, C.H., PINTO, T.J.A. Rapid determination of neomycin by a microbiological agar diffusion assay using triphenyltetrazolium chloride. J. Assoc. Off. Anal. Chem., v.79, n.2, p.434-440, 1996.

Received for publication on $12^{\text {th }}$ November 2007 Accepted for publication on $7^{\text {th }}$ May 2009 